\title{
Holocene climate change, permafrost and cryogenic carbonate formation: insights from a recently deglaciated, high-elevation cave in the Austrian Alps
}

\author{
C. Spötl ${ }^{1}$ and H. Cheng ${ }^{2}$ \\ ${ }^{1}$ Institute of Geology, University of Innsbruck, Innrain 52, 6020 Innsbruck, Austria \\ ${ }^{2}$ Institute of Global Environmental Change, Xi' an Jiaotong University, Xi' an 710049, China \\ Correspondence to: C. Spötl (christoph.spoetl@uibk.ac.at)
}

Received: 21 March 2014 - Published in Clim. Past Discuss.: 9 April 2014

Revised: 11 June 2014 - Accepted: 17 June 2014 - Published: 22 July 2014

\begin{abstract}
Cryogenically formed carbonate particles represent a rather new class of speleothems whose origin is directly linked to the presence of perennial ice in the subsurface. Recent studies concluded that dating these deposits provides important time constraints on the presence and the thickness of permafrost, e.g., during the last glacial period. More precisely, these carbonates record episodes of progressive karst water freezing. Such conditions have been associated with periods of permafrost thawing allowing the infiltration of meltwater into formerly dry, frozen caves.

To shed more light on the origin of the coarsely crystalline variety of these cryogenic cave carbonates $-\mathrm{CCC}_{\text {coarse }}$ for short - we examined a high-elevation cave site in the western part of the Austrian Alps which is located in an area dominated by permafrost features and transformed from an ice cave into an essentially ice-free cave during the past decade. Two side chambers of the main gallery revealed cryogenic calcite deposits whose isotopic composition indicates that they formed in individual pools of water carved in ice which underwent very slow freezing under closed-system conditions, i.e., enclosed in ice. ${ }^{230} \mathrm{Th}$ dating shows that most of these carbonates formed ca. $2600 \mathrm{yr}$ BP. Based on comparisons with other palaeoclimate archives in the Alps this thawing episode did not occur during a climate optimum, nor did $\mathrm{CCC}_{\text {coarse }}$ form in this cave during, e.g., the Roman or the Medieval Warm Periods. Our results suggest that the occurrence of $\mathrm{CCC}_{\text {coarse }}$, at least in mountain regions characterized by discontinuous permafrost, may be more stochastic than previously thought. Given the inherent heterogeneity of karst aquifers and the important role of localized water infil-
\end{abstract}

tration in modifying the thermal structure of the subsurface, we caution against attributing $\mathrm{CCC}_{\text {coarse }}$ occurrences solely to peak warming conditions, while confirming the unique significance of these deposits in providing robust age constraints on permafrost thawing episodes.

\section{Introduction}

Permafrost is an important but only partly visible element of high mountain ranges such as the Alps. In the Eastern Alps of Austria discontinuous and continuous permafrost is widespread at altitudes above 2500-2600 and 3000-3500 m a.s.l., respectively (e.g., Krainer and Ribis, 2012; Schöner et al., 2012). In the Central Alps, the aerial extent of permafrozen ground above $2500 \mathrm{~m}$ a.s.l. exceeds the area occupied by glaciers. Given the potential hazards associated with its degradation due to rising air temperatures, Alpine permafrost has been extensively studied and its physics is well understood (e.g., Gruber et al., 2004; Huggel et al., 2010; Boeckli et al., 2012; Springman et al., 2013). Much less well known, however, are changes in permafrost thickness and aerial extent on decadal, centennial and millennial timescales, largely because of lack of suitable archives.

A new class of chemical sediments has emerged in recent years that may help to fill this gap by providing information on the past presence of perennial ice in the subsurface. Known as cryogenic cave carbonates (CCC) these deposits occur in caves and occur in a great variety of particles typically composed of low-Mg calcite (Žák et al., 2012). Their 
origin has been attributed to freezing of water as thin film or as shallow pools on cave ice, and hence they provide direct evidence for the former presence of ice in caves that are ice-free today. Two types of CCC are known: fine crystalline, powder-like deposits $\left(\mathrm{CCC}_{\text {fine }}\right)$ and coarsely crystalline particles $\left(\mathrm{CCC}_{\text {coarse }}\right)$. Only the former variety has been observed in statu nascendi in ice caves. A key aspect of $\mathrm{CCC}_{\text {coarse }}$ is that the age of these crystals can be determined using ${ }^{230} \mathrm{Th}$, thus providing temporal constraints on the presence of subsurface ice in the past (which is otherwise hardly possible). $\mathrm{CCC}_{\text {fine }}$, in theory, can also be dated using this method. Tests have shown, however, that the high degree of detrital contamination commonly found in these samples (given their high surface area) renders ${ }^{230} \mathrm{Th}$-dating difficult, in particular if they are less than a few thousand years old (C. Spötl, unpublished data).

Previous research on CCC has focused on cave sites located in the periglacial corridor between the former Scandinavian and the Alpine ice sheets (e.g., Žák et al., 2004, 2008, 2012; Richter et al., 2010, 2013; Orvošová et al., 2014), and ${ }^{230} \mathrm{Th}$ dates from caves in the Czech Republic, Germany, Slovakia and Poland provide important constraints on the timing and depth distribution of permafrozen ground during the last glacial period and the Lateglacial period (see review by Žák et al., 2012). Only very few reports of CCC exist from caves in the Alpine realm, which may reflect the fact that this mountain range was occupied by a dendritic ice-stream network during glacial maxima. Two occurrences of $\mathrm{CCC}_{\text {coarse }}$ have been reported from Alpine caves so far. Richter et al. (2009) published data on $\mathrm{CCC}_{\text {coarse }}$ from an ice cave in the German part of the Eastern Alps (Glaseis Cave, no ${ }^{230} \mathrm{Th}$ dates available), and Luetscher et al. (2013) reported ${ }^{230}$ Th-dated $\mathrm{CCC}_{\text {coarse }}$ deposits from Leclanché, a partly deglaciated cave in the Sanetsch area of western Switzerland. $\mathrm{CCC}_{\text {fine }}$ is more common based on our own observations in Alpine caves, but to our knowledge published reports only exist for Monlesi, a small ice cave in the Swiss Jura Mountains (Luetscher et al., 2007), Eisriesenwelt in Salzburg (Spötl, 2008; May et al., 2011), as well as for Leclanché Cave (Luetscher et al., 2013).

The aim of this communication is to report the discovery of $\mathrm{CCC}_{\text {coarse }}$ in a cave from the Austrian Alps. Using field observations, petrography, stable isotopes and ${ }^{230} \mathrm{Th}$ dating, we shed light on the origin of these deposits and evaluate their formation in the context of the late Holocene climate evolution of the Alps.

\section{Study site}

Mitterschneidkar Eishöhle, hereafter referred to as MSK Cave, Austrian cave cadaster no. 2516/6, is located on the Tuxer Hauptkamm, which forms the westernmost branch of the Zillertal Alps (Figs. 1 and 2). The cave opens at $2558 \mathrm{~m}$ a.s.l. next to an active rock glacier and consists of

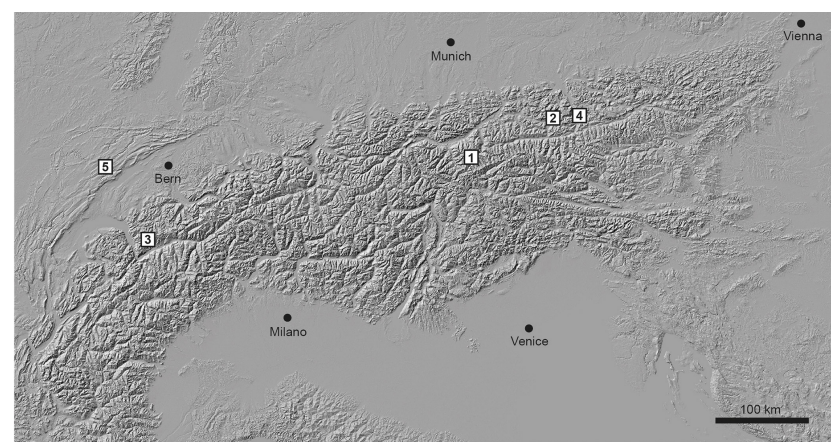

Figure 1. Elevation map of the Alps showing the currently known

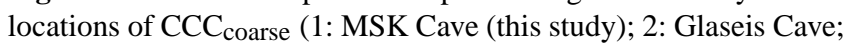
3: Leclanché Cave) and $\mathrm{CCC}_{\text {fine }}$ (4: Eisriesenwelt; 5: Monlesi Cave; as well as also in Leclanché Cave, no. 3).

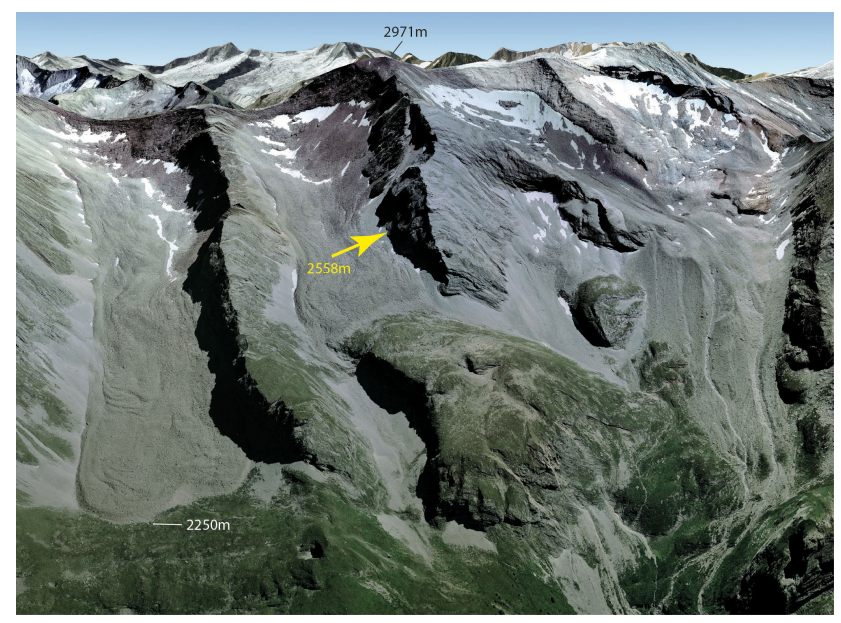

Figure 2. Oblique aerial view of the setting of the MSK Cave (entrance marked by the yellow arrow) at the Tuxer Hauptkamm, Zillertal Alps. Note active rock glaciers occupying the cirques and reaching down to $2250 \mathrm{~m}$ in case of the rock glacier in the left cirque. View to the southeast (Google Earth Pro image).

a single descending gallery following the ca. $40^{\circ}$ dip of the Upper Jurassic Hochstegen Marble (Figs. 2 and 3). The main gallery terminates in an impassable fracture and no air flow was noticed at this lower end. The gallery is characterized by strong frost shattering modifying the original phreatic tube and giving rise to abundant angular rubble covering the cave floor.

MSK Cave was discovered in 2004. In 2005, when the cave was first surveyed, up to $5 \mathrm{~m}$ thick congelation ice was present in the upper part of the main gallery, whose bedding followed the dip of the gallery and whose surface already showed clear signs of ongoing melting (Fig. 4a-c). When we revisited the cave in 2007, the ice was further reduced and before 2012 (no visits to the cave in between) all ice was gone. The previously ice-covered areas were carefully inspected but no CCC deposits were observed. We noticed, 


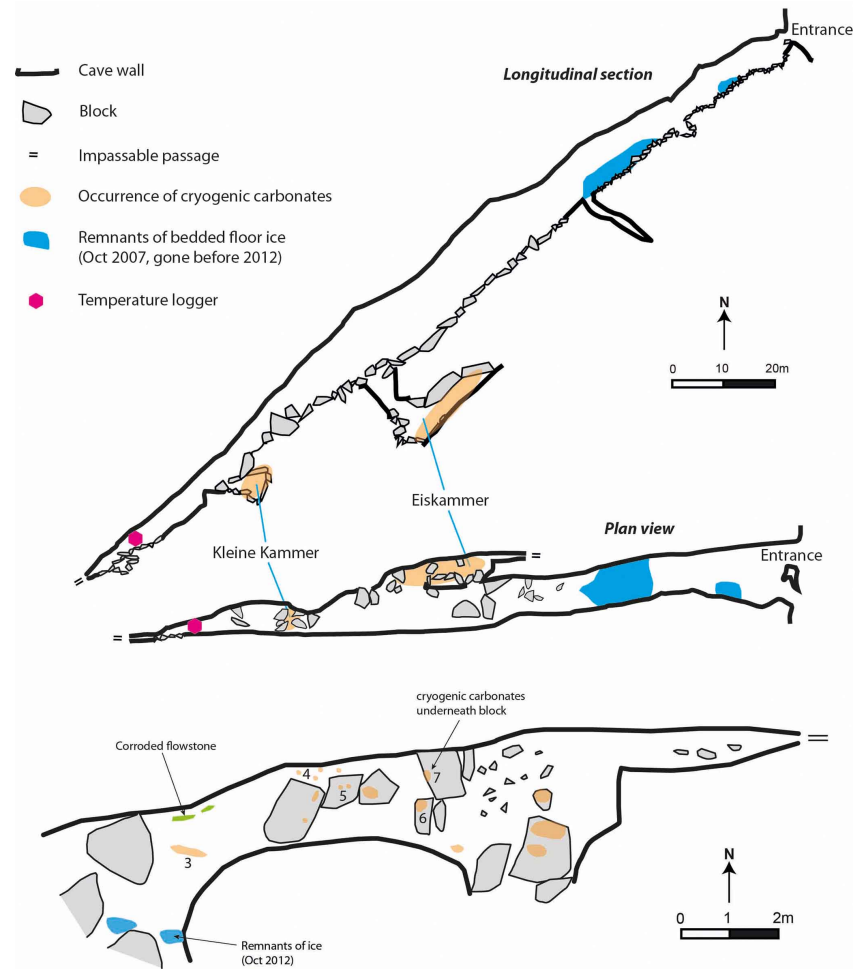

Figure 3. Longitudinal section and plan view of MSK Cave, showing the occurrence of $\mathrm{CCC}_{\text {coarse }}$ (light brown), and enlargement of the plan view of the Eiskammer (lower panel). Cave survey by C. Spötl and G. Moseley. Numbers refer to samples of $\mathrm{CCC}_{\text {coarse }}$ sampled in this study, whereby MSK1 and 2 were obtained from the Kleine Kammer and MSK3 to 7 from the Eiskammer.

however, the presence of aggregates of rubble coated and intermixed with small amounts of unsorted sediment ranging from fine sand to very angular clasts up to a few centimeters in diameter (Fig. 4d). The fabric of this rubble was strikingly loose compared to other, e.g., lower parts of the gallery, and sandy sediment is otherwise uncommon in this cave. The fact that these loose blocks associated with the fine, unsorted sediment are only present in recently deglaciated parts of the cave suggests deposition of the debris following ice melting. We therefore consider these localized deposits as an equivalent of melt-out till.

CCC was only observed in two chambers off the main gallery: in the Eiskammer and a smaller chamber further downslope referred to as Kleine Kammer (Fig. 3).

Limited drip water was present in the deeper parts of the cave during summer and fall (no observations during the other seasons), which demonstrates that the rock above the cave is not permafrozen today. No water enters the cave by the entrance.

Cave air temperature near the lower end of the main gallery was logged between October 2005 and May 2011 and showed a mean value of $0.23^{\circ} \mathrm{C}$ with minimum and maximum temperatures at the end of November and typically in September, respectively (Fig. 5). The interior part of the cave does not record the lowest outside temperatures that occur typically in January, suggesting that the cave entrance is likely sealed by wind-blown snow after November.

\section{Methods}

The morphology of cryogenic crystals and the fine fraction of the melt-out till were examined using reflected-light, transmitted-light and blue-light epifluorescence microscopy (thin sections of crystals impregnated in epoxy resin), as well as using field-emission scanning electron microscopy (FESEM). The mineralogical composition of the cryogenic crystals was determined using powder X-ray diffraction (XRD). CCC crystals were handpicked using a binocular microscope and several aliquots $(0.05-0.2 \mathrm{mg})$ were analyzed for their stable isotope composition following the methodology of Spötl and Vennemann (2003). Isotope ratios are reported on the VPDB scale and the long-term 1-sigma precision is 0.06 and $0.08 \%$ for $\delta^{13} \mathrm{C}$ and $\delta^{18} \mathrm{O}$, respectively.

Samples for ${ }^{230} \mathrm{Th}$ dating (ca. $20-30 \mathrm{mg}$ each) were also handpicked using a binocular microscope. U-Th chemistry and isotopic measurements on a Thermo Fisher NEPTUNE multi-collector inductively coupled plasma mass spectrometer (MC-ICP-MS) were performed at the Institute of Global Environmental Change, Xi' an Jiaotong University. U-Th isotopic data were calculated using recently revised ${ }^{230} \mathrm{Th}$ and ${ }^{234} \mathrm{U}$ half-lives (Cheng et al., 2013), and the uncertainties at the 2-sigma level include corrections for blanks, multiplier dark noise, abundance sensitivity and contents of nuclides in the spike solution. The elevated ${ }^{232} \mathrm{Th}$ content required a correction which assumed an initial ${ }^{230} \mathrm{Th} /{ }^{232} \mathrm{Th}$ atomic ratio of $4.4 \pm 2.2 \times 10^{-6}$. This is the value for material at secular equilibrium, with a bulk earth ${ }^{232} \mathrm{Th} /{ }^{238} \mathrm{U}$ value of 3.8 . The errors are arbitrarily assumed to be $50 \%$. Ages are reported in years BP, i.e., before the year $1950 \mathrm{AD}$.

\section{Results}

\subsection{Occurrence of $\mathrm{CCC}_{\text {coarse }}$}

In both chambers $\mathrm{CCC}_{\text {coarse }}$ is present as patches (heaps) 0.5 to $1 \mathrm{~m}$ in diameter consisting of loose crystals (Figs. 3 and 6a). Scattered CCC crystals were locally also observed in between these patches. The thickness of these small heaps of crystals does not exceed ca. $1 \mathrm{~cm}$ and typically is about $5 \mathrm{~mm}$ only (Fig. 6b). Heaps of crystals are present on breakdown blocks with both horizontal or tilted surfaces, on steep cave walls (where the crystals are more widely spread) and in one instance also underneath a block which forms kind of a roof above this small heap (Fig. 3). Two samples (MSK1 and 2; Fig. 6c) were taken from the Kleine Kammer and five samples were obtained from five individual heaps in the Eiskammer (MSK3 to 7; Fig. 3). MSK1 and MSK2 represent two 

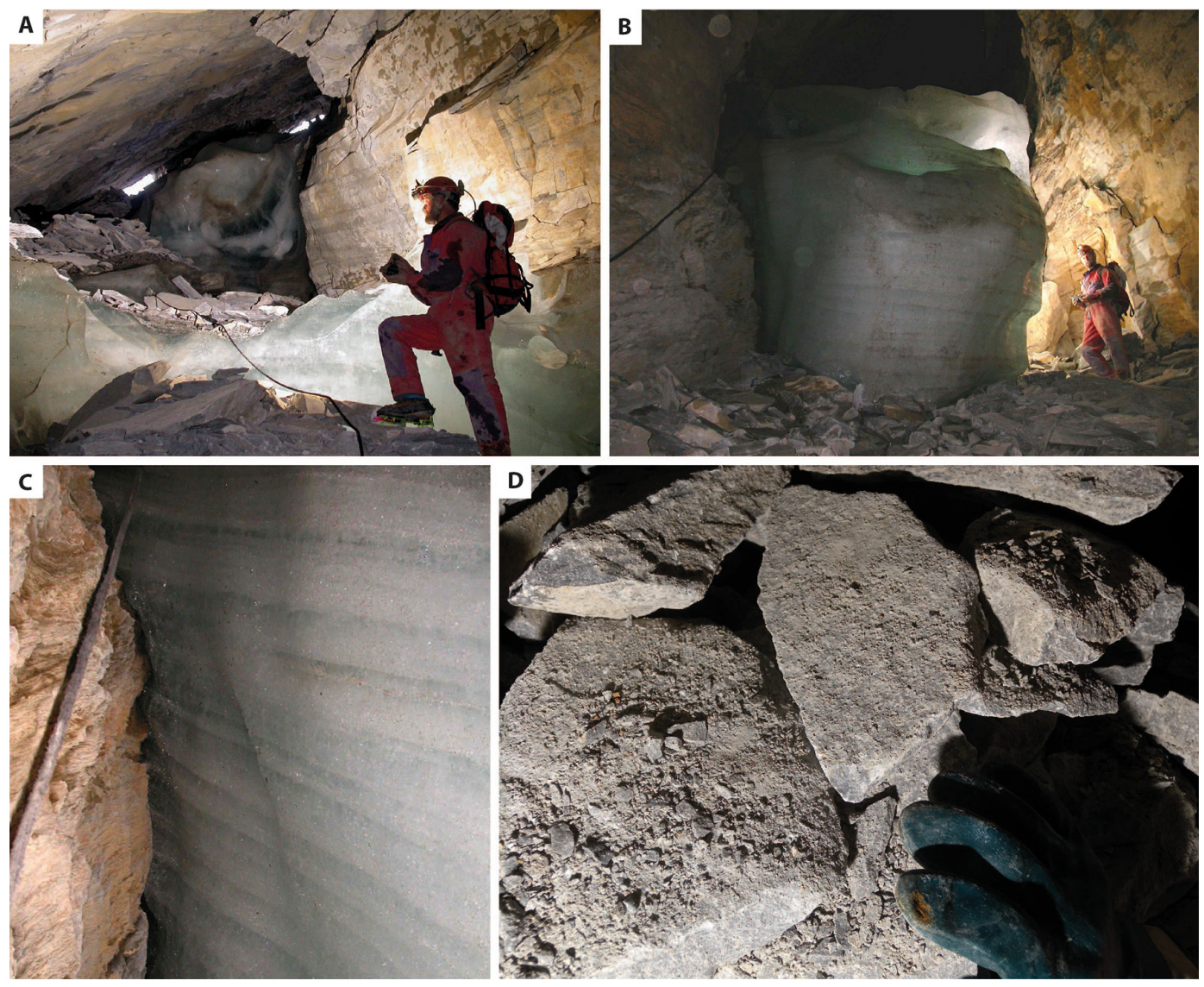

Figure 4. Ice and related features in MSK Cave. (a) View upwards towards the entrance which was partially ice-plugged in October 2005. (b) Lower end of the second ice body in October 2005. (c) Close-up of the ice cliff showing the banded ice stratigraphy. Height of image: $1 \mathrm{~m}$. (d) Melt-out till consisting of angular blocks and intermixed sand deposited since 2005; glove in the right-hand bottom corner for scale.

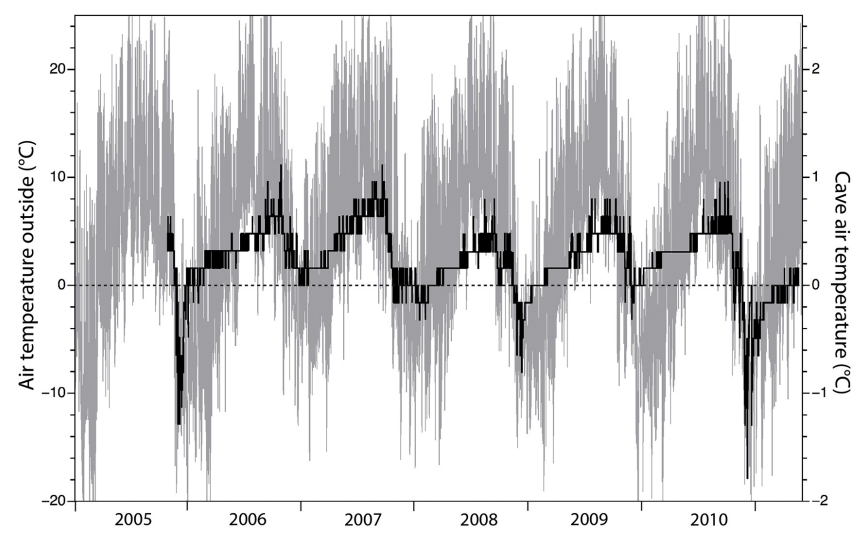

Figure 5. The air temperature near the lower end of MSK Cave (black) mirrors the outside temperature changes (grey) until about November; afterwards the cave air temperature for most of the years is decoupled from the outside air, suggesting that snow clogs the entrance during winter. The outside temperature was recorded at Spannagel Hut located at $2531 \mathrm{~m} 6.5 \mathrm{~km}$ southwest of MSK Cave. different size fractions: MSK1 comprises the largest particles (up to ca. $2 \mathrm{~cm}$ in diameter), whereas MSK2 is an aliquot of the finer fraction comprising crystal aggregates typically only up to a few millimeters in size.

\subsection{Petrography}

CCC crystals from MSK Cave range in diameter between fractions of a millimeter up to $2 \mathrm{~cm}$. The typical crystal size is in the millimeter range. Macroscopically, two populations of crystals and crystal aggregates were observed: brown and white ones (Fig. 7a and b). All heaps are mixtures of both types (Fig. 6b), but the percentage of the white crystal fraction is much lower in the Kleine Kammer compared to the Eiskammer. We did not notice a systematic pattern in the abundance of brown and white types within the two chambers nor within individual heaps.

Both crystal populations are pure calcite according to X-ray diffraction analyses. We also sampled a partly corroded flowstone coating the cave wall in the Eiskammer and found calcite and, less abundantly, aragonite layers inside this $1-2 \mathrm{~cm}$ thick deposit. 

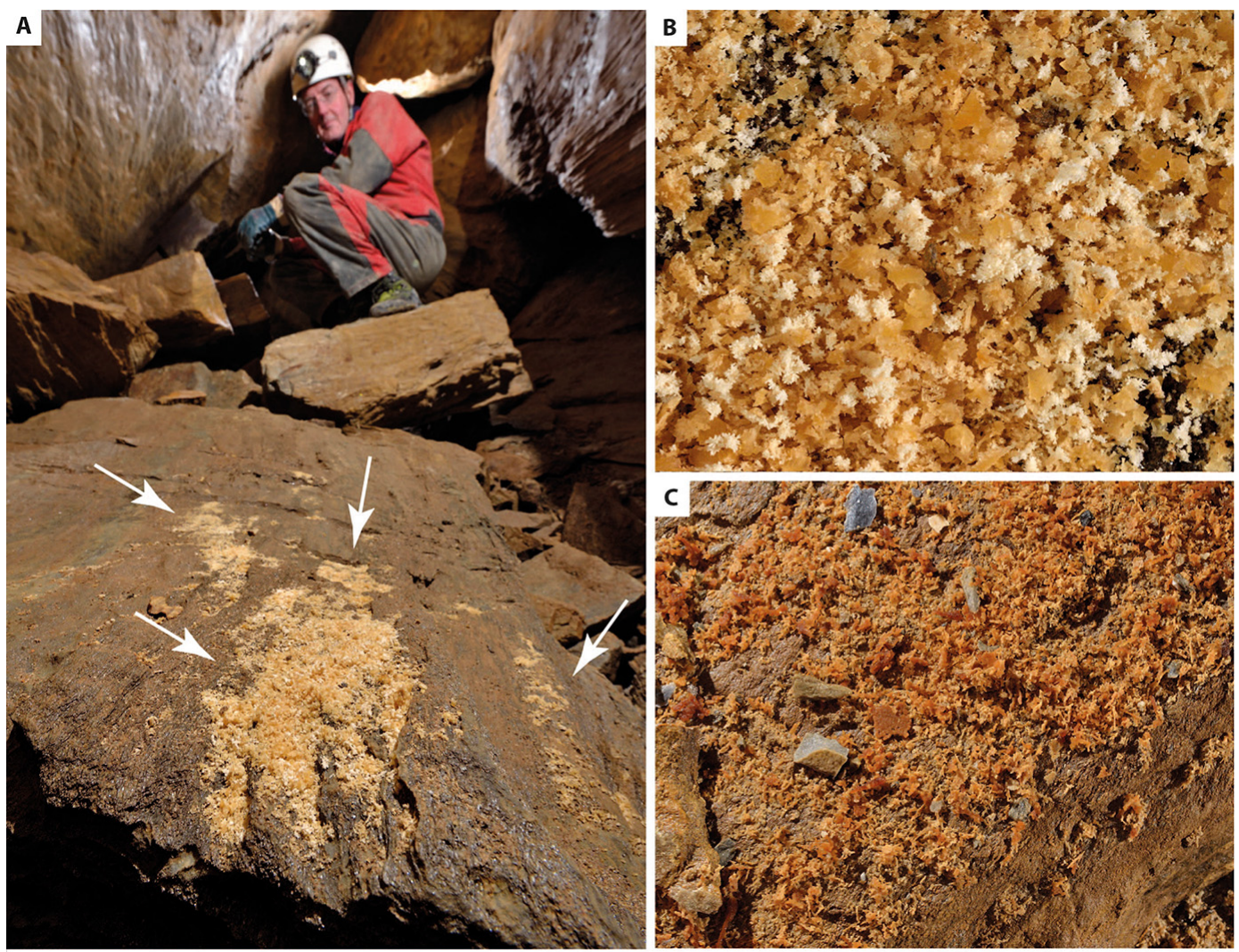

Figure 6. Cryogenic calcite deposits in MSK Cave. (a) Typical occurrence of heaps of loose crystal aggregates (arrows) in the Eiskammer chamber (sample MSK5). (b) Close-up of cryogenic deposit in the Eiskammer, consisting of brown and white crystal aggregates. Width of image $5 \mathrm{~cm}$. (c) Occurrence of loose brownish crystal aggregates intermixed with a few angular rock flakes on a boulder in the Kleine Eiskammer. Width of image $25 \mathrm{~cm}$.

The sand fraction of the melt-out till was examined for the presence of carbonate crystals of possible cryogenic origin, but only angular rock fragments and no indication of euhedral crystals or aggregates thereof were found.

According to optical and FE-SEM studies the two macroscopic crystal populations also show different micromorphologies. The brown fraction consists of rhombohedral crystals and aggregates thereof. The color of these crystals ranges from yellowish brown to medium brown and only the former ones show some transparency. The brown CCC aggregates commonly show raft-like morphologies, i.e., platelets with different bottom and top sides (Figs. 7a and 8a). Fragments of such raft-like forms are common as well. These aggregates consist of rhombohedra showing an obtuse habit; steep rhombohedra are absent (Fig. 8b and c). Dendritic crystals were also observed and a small percentage of the brown CCC fraction consists of small, rosette-like aggregates with rhombohedral crystal radiating in all directions. In contrast, the white crystal fraction is composed of elongate crystals which appear conspicuously opaque white in reflected light (Fig. 7b). At first glance, their habit resembles aragonite rays, but FE-SEM observations reveal that they are actually composed of bundles of tree-like subcrystals (Fig. 8d-f) made entirely of calcite (confirmed by XRD). Combinations of the two crystal populations are virtually absent.

Thin-section microscopy confirmed these observations and showed that the brown crystal fraction consists of rhombohedral crystals and aggregates thereof which even show extinction under cross-polarized light and a low degree of impurities (Fig. 9a, b, d and e). Aggregates are composed of a number of smaller crystals showing slightly deviating extinction behaviors. In contrast, the elongate crystals of the white fraction appear brownish in transmitted light due to a high abundance of intracrystalline boundaries and minute impurities which could not be resolved even at high magnification (Fig. 9g-h). Both types of calcite crystals uniformly show moderately bright fluorescence (Fig. 9c, f and i) and no evidence of zoning.

\subsection{Stable isotopic composition}

The brown and white crystal fractions overlap in their $\mathrm{C}$ but not in their $\mathrm{O}$ isotopic composition, whereby the brown crystals show more depleted $\delta^{18} \mathrm{O}$ values (as low as $-20.9 \%$ o) 

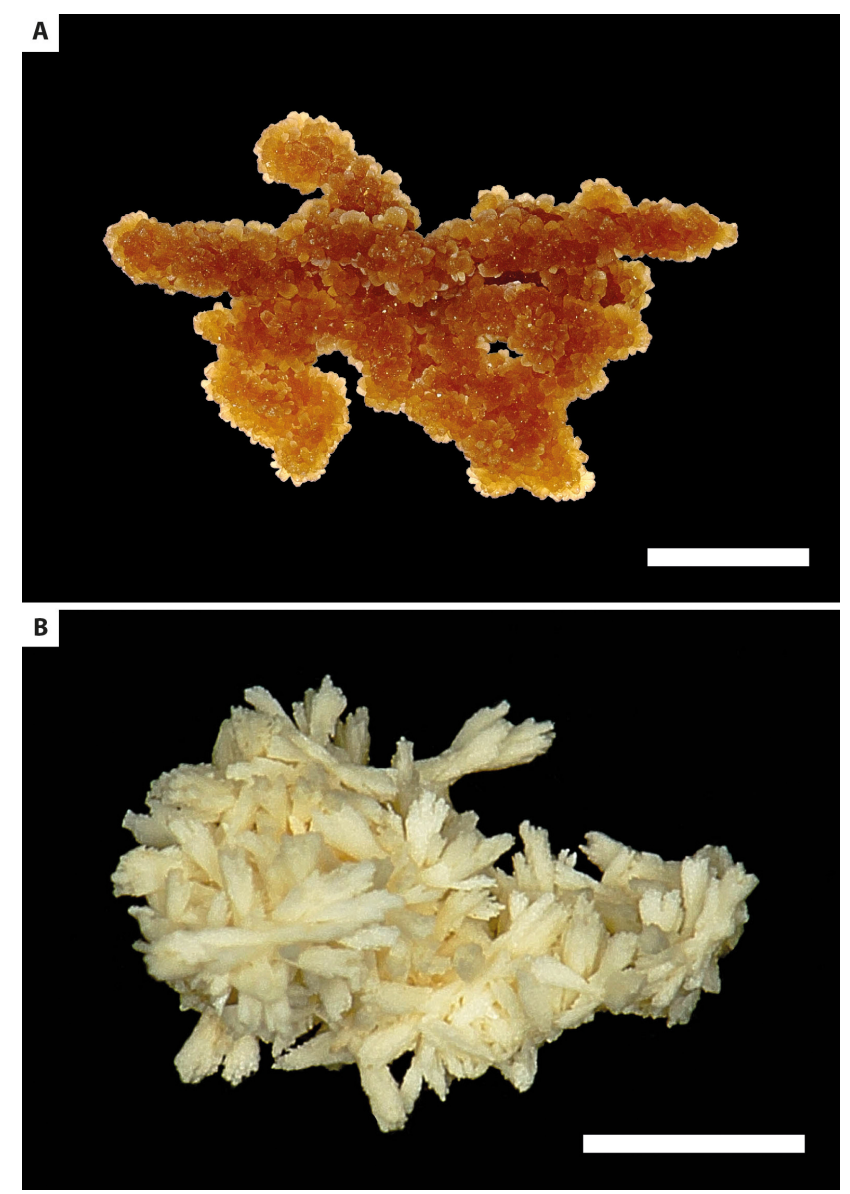

Figure 7. Morphology of cryogenic calcite crystals in normal reflected light. (a) Typical brown crystal aggregate; sample MSK1. Scale bar $3 \mathrm{~mm}$. (b) White crystal aggregate; sample MSK5. Scale bar $1 \mathrm{~mm}$.

but higher $\delta^{13} \mathrm{C}$ values (up to $+7.9 \%$ ) compared to the white fraction (Fig. 10). This is also the case for samples from different heaps. Several heaps are characterized by a unique isotopic composition of the two crystal fractions (Fig. 10), and the differences in both isotopes comprises several per mill. The two samples from the Kleine Kammer (MSK1 and 2) differ isotopically from samples MSK3 to 7 from the Eiskammer (Fig. 10).

The isotopic composition of the inactive, partly corroded flowstone in the Eiskammer shows much higher $\delta^{18} \mathrm{O}$ values for both calcite and aragonite layers than $\mathrm{CCC}_{\text {coarse }}$ (Fig. 10).

\subsection{Age dating}

$\mathrm{U}$ concentrations of cryogenic calcites range from 1.6 to $7.4 \mathrm{ppm}$, whereby the brown crystals have higher values than the white ones (3.0-7.4 vs. 1.6-2.4 ppm). Most samples contain substantial detrital Th as reflected by the low ${ }^{230} \mathrm{Th} /{ }^{232} \mathrm{Th}$ ratio (Table 1 ). The corrected dates vary between $1739 \pm 39$ and $4544 \pm 2886 \mathrm{yr}$ BP. Excluding two samples which show by far the highest detrital contamination (4W and $5 \mathrm{~W}$ ) results in a narrower dating range of $1739 \pm 39$ to $3045 \pm 578 \mathrm{yr} \mathrm{BP}$. This range is defined by the brown crystal fraction and the only moderately precise measurement of the white crystal fraction falls inside this range $(2715 \pm 660$ yr BP).

We also sampled the corroded flowstone which yielded high ages of $203 \pm 4$ and $312 \pm 10 \mathrm{kyr}$ (measured using thermal ionization mass spectrometry by A. Mangini and R. Eichstädter, Heidelberg, personal communication, 2008).

\section{Discussion}

\subsection{Characteristics of $\mathbf{C C C}_{\text {coarse }}$}

$\mathrm{CCC}_{\text {coarse }}$ has never been observed in statu nascendi and most dated occurrences in central European caves are from the last glacial period (Žák et al., 2012; Richter et al., 2013; Orvošová et al., 2014). Interestingly, the youngest currently known occurrence is from a cave in the Swiss Alps located at the threshold of modern permafrost and dates from the medieval period (Luetscher et al., 2013). MSK Cave is also from an area characterized by permafrost with active rock glaciers nearby (Fig. 2). This new site shows many similarities with previously known $\mathrm{CCC}_{\text {coarse }}$ occurrences and adds some new observations which help to better constrain the mode of $\mathrm{CCC}_{\text {coarse }}$ formation by studying a recently deglaciated highelevation cave.

MSK site has several aspects in common with previously studied $\mathrm{CCC}_{\text {coarse }}$ occurrences:

(a) Localized occurrence within a given cave. Although the main descending gallery in the MSK Cave until very recently contained ice several meters thick, $\mathrm{CCC}_{\text {coarse }}$ only formed in two side chambers far from the entrance; these were obviously also ice-filled at some point allowing the formation of these cryogenic minerals. This is consistent with observations from other caves where $\mathrm{CCC}_{\text {coarse }}$ typically also formed in the deep interior (Žák et al., 2012; Richter et al., 2009), where ventilation was very limited and stable thermal conditions prevailed.

(b) Patchy distribution within a given cave chamber. In both chambers of the MSK Cave the crystals are not evenly distributed but form patches or heaps with very few crystals in between. A very similar mode of occurrence has been reported from other caves. In their review paper Žák et al. (2012, their supplement) provide instructive pictures which strongly resemble the situation in MSK Cave.

(c) Lack of cementation. The loose nature of these thin deposits is another common feature of $\mathrm{CCC}_{\text {coarse }}$ occurrences in MSK and other studied caves. The lack of mechanical compaction features strongly suggests that 

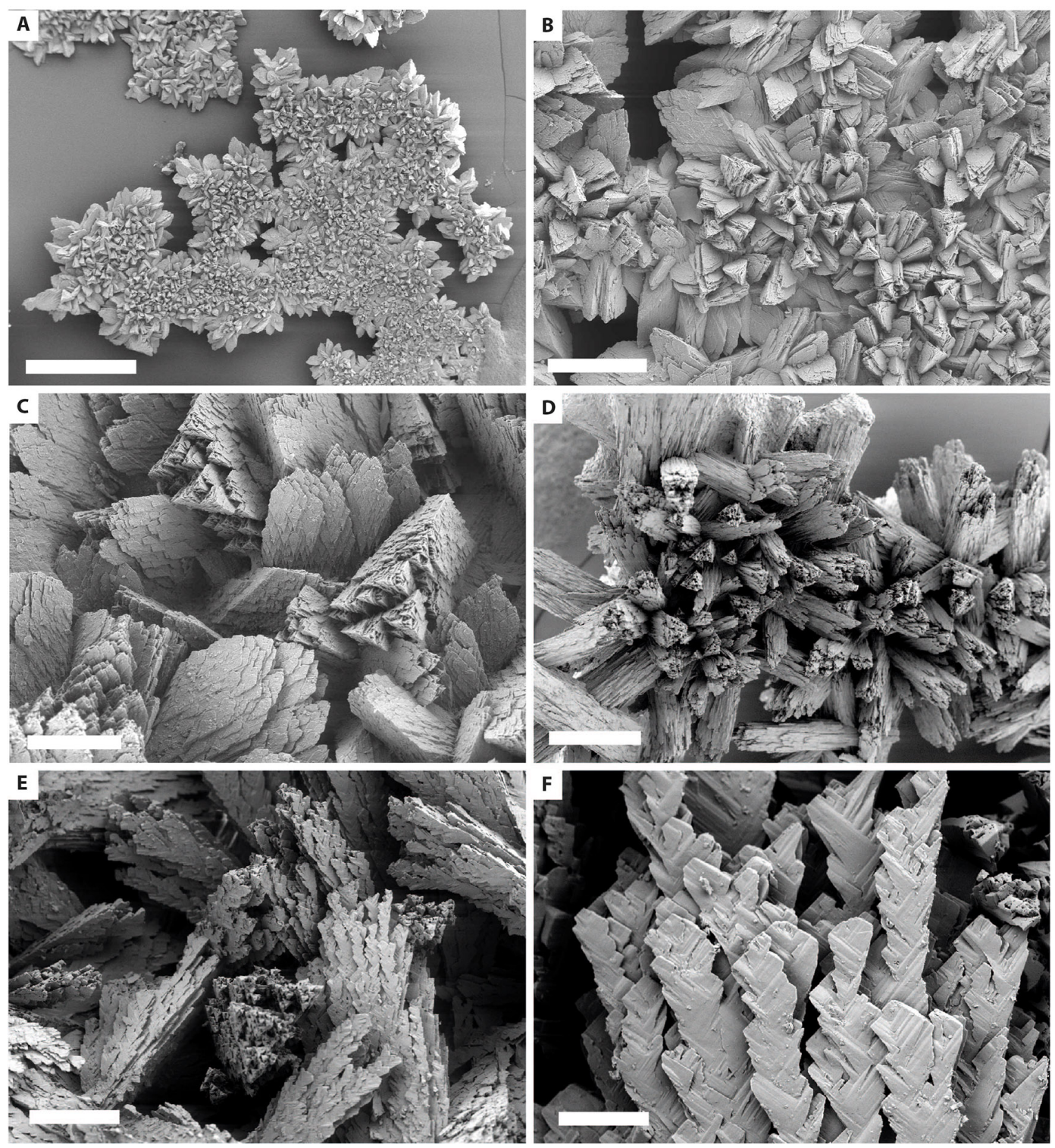

Figure 8. Morphology of cryogenic calcite crystals seen under the FE-SEM. (a) Calcite raft; sample MSK5B. Scale bar 1 mm. (b) Closeup of (a). Scale bar $0.2 \mathrm{~mm}$. (c) Stepped faces on individual rhombohedral crystals; sample MSK6B. Scale bar 0.1 mm. (d) White crystal aggregate; sample MSK3W. Scale bar $0.2 \mathrm{~mm}$. (e) Details of white crystal morphology; sample MSK5W. Scale bar $0.1 \mathrm{~mm}$. (f) Close-up of (e), revealing chevron-type crystal habits. Scale bar $0.02 \mathrm{~mm}$.

once the ice was completely gone and the calcite crystals were released the ice did not regrow. Subsequent vadose speleothem deposition was absent in MSK Cave and is also rather uncommon in other studied sites.

(d) Characteristic petrographic types of $\mathrm{CCC}_{\text {coarse }}$ crystals. Many of the types of crystals found in MSK Cave have previously been reported from other formerly icebearing caves, including rhombohedral crystals (Richter et al., 2009, 2010), rafts (Žák et al., 2012, Supplement), opaque-white crystals (Orvošová et al., 2014) and rosette-like crystal aggregates (Žák et al., 2013). On the other hand, a few types of cryogenic calcite crystal (aggregates) have not been observed in MSK Cave. These include spheroids, either as individual spheres or aggregates thereof (e.g., recently described from Leclanché Cave; Luetscher et al., 2013), spheres with a dent on one site (also known as cupulas; Richter and Riechelmann, 2008) and spherulitic crystal aggregates ranging from dumbbell-shaped to braided (Erlemeyer et al., 1992; Richter et al., 2010). Too little is known about the mode of formation of these morphological types to draw firm conclusions about the fact that they are present in many but not all caves containing $\mathrm{CCC}_{\text {coarse }}$. 
Table 1. ${ }^{230}$ Th dating results of cryogenic calcite samples from MSK Cave. Sample numbers refer to those in Fig. 1 (lower panel), and the letter indicates the petrographic type: B - brown crystals; W - white crystals. Two samples were excluded (italics) because of their excessive ${ }^{232}$ Th values. $\delta^{234} \mathrm{U}=\left(\left[{ }^{234} \mathrm{U} /{ }^{238} \mathrm{U}\right]_{\text {activity }}-1\right) \times 1000 . \delta^{234} \mathrm{U}_{\text {initial }}$ was calculated based on ${ }^{230} \mathrm{Th}$ age $(T)$, i.e., $\delta^{234} \mathrm{U}_{\text {initial }}=$ $\delta^{234} \mathrm{U}_{\text {measured }} \times e^{\lambda 234 \times T}$. Ages are reported as BP, i.e., before the year $1950 \mathrm{AD}$. The error is 2 sigma.

\begin{tabular}{|c|c|c|c|c|c|c|c|c|}
\hline Sample & $\begin{array}{l}{ }^{238} \mathrm{U} \\
(\mathrm{ppb})\end{array}$ & $\begin{array}{l}{ }^{232} \mathrm{Th} \\
\text { (ppt) }\end{array}$ & $\begin{array}{l}{ }^{230} \mathrm{Th} /{ }^{232} \mathrm{Th} \\
\left(\text { atomic } \times 10^{-6}\right)\end{array}$ & $\begin{array}{l}\delta^{234} \mathrm{U} \\
\text { (measured) }\end{array}$ & $\begin{array}{l}{ }^{230} \mathrm{Th} /{ }^{238} \mathrm{U} \\
\text { (activity) }\end{array}$ & $\begin{array}{l}{ }^{230} \text { Th age (yr) } \\
\text { (uncorr.) }\end{array}$ & $\begin{array}{l}\delta^{234} \mathrm{U}_{\text {initial }} \\
\text { (corr.) }\end{array}$ & $\begin{array}{l}{ }^{230} \text { Th age }(y r) \\
\text { (corr.) }\end{array}$ \\
\hline MSK1B & $2974 \pm 10$ & $29503 \pm 591$ & $30 \pm 1$ & $-353.6 \pm 1.6$ & $0.0182 \pm 0.0001$ & $3125 \pm 25$ & $-356 \pm 2$ & $2614 \pm 319$ \\
\hline MSK3B & $5065 \pm 17$ & $33837 \pm 687$ & $46 \pm 1$ & $-305.4 \pm 1.8$ & $0.0188 \pm 0.0001$ & $2993 \pm 24$ & $-308 \pm 2$ & $2649 \pm 200$ \\
\hline MSK4B & $4840 \pm 12$ & $85526 \pm 1727$ & $21 \pm 1$ & $-363.9 \pm 1.6$ & $0.0224 \pm 0.0002$ & $3924 \pm 37$ & $-367 \pm 2$ & $3045 \pm 578$ \\
\hline$M S K 4 W$ & $2426 \pm 5$ & $698208 \pm 14044$ & $5 \pm 1$ & $-350.7 \pm 1.5$ & $0.0944 \pm 0.0009$ & $17385 \pm 185$ & $-354 \pm 10$ & $3359 \pm 9828$ \\
\hline MSK6B & $7427 \pm 17$ & $8688 \pm 176$ & $167 \pm 4$ & $-293.5 \pm 1.5$ & $0.0119 \pm 0.0001$ & $1850 \pm 20$ & $-295 \pm 2$ & $1739 \pm 39$ \\
\hline MSK6W & $1715 \pm 3$ & $38955 \pm 781$ & $17 \pm 1$ & $-283.6 \pm 1.1$ & $0.0239 \pm 0.0004$ & $3707 \pm 58$ & $-286 \pm 1$ & $2715 \pm 660$ \\
\hline MSK7B & $4955 \pm 17$ & $123725 \pm 2482$ & $16 \pm 1$ & $-291.0 \pm 1.7$ & $0.0237 \pm 0.0002$ & $3722 \pm 28$ & $-293 \pm 2$ & $2626 \pm 731$ \\
\hline
\end{tabular}
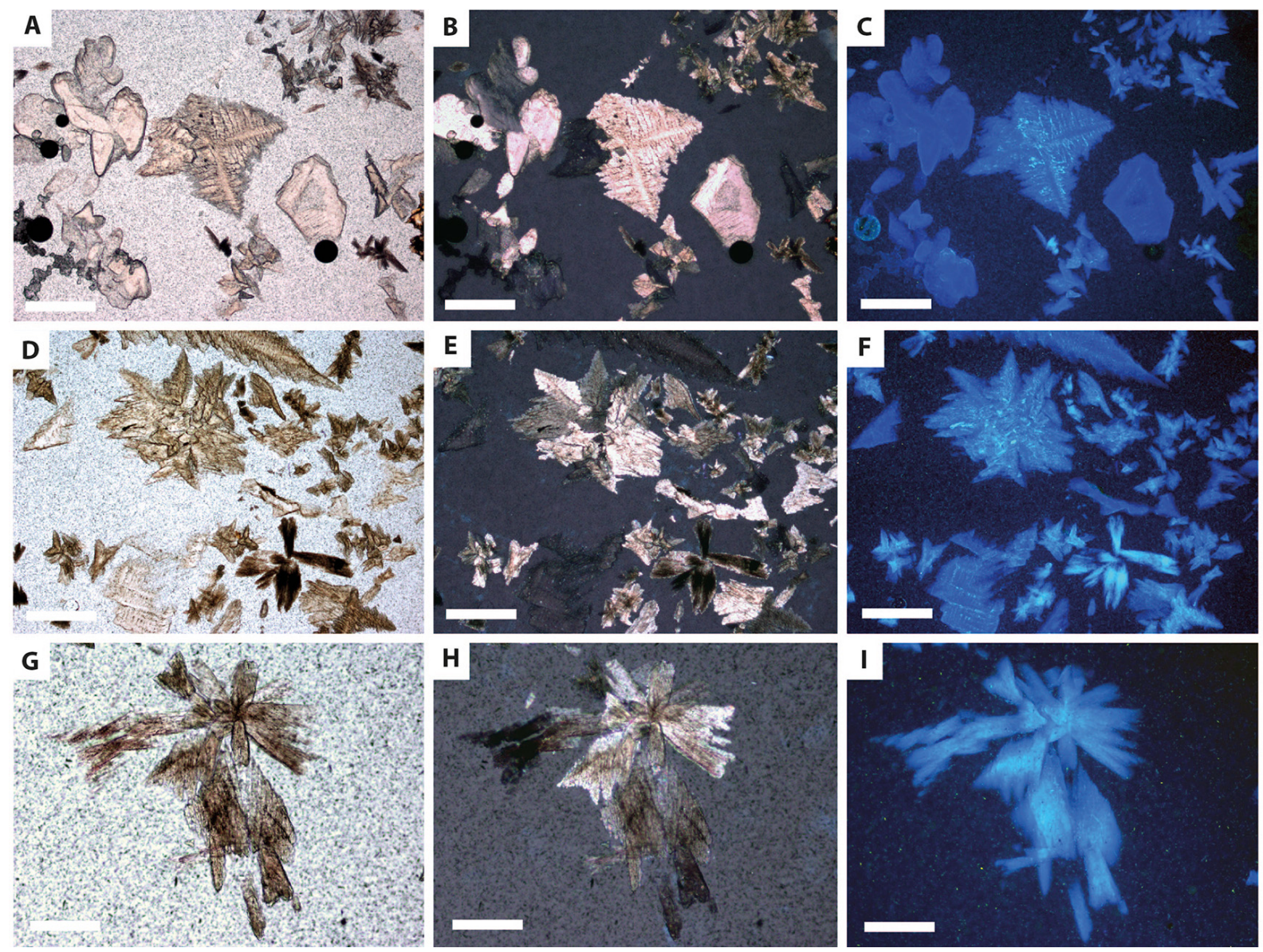

Figure 9. Appearance of cryogenic calcite crystals in thin sections. (a) Dendritic crystal (center) and fragments of rhombohedral crystals nearby as well as smaller aggregates of the white crystal population (e.g., right-hand upper corner of image). Plane-polarized light. (b) Same under partially cross-polarized light. (c) Same under epifluorescence. In (a-c) black rounded spots are air bubbles in the epoxy resin. (d) Mixture of aggregates of rhombohedral crystals, spear-like aggregates (partially visible near upper margin of the image) and few aggregates of the white crystal population (lower right corner). (e) Same under cross-polarized light. (f) Same under epifluorescence. (g) Close-up of a rosette-like aggregate of the white crystal population, which appears brown and rich in minute inclusions in transmitted light. (h) Same under partially cross-polarized light. (i) Same under epifluorescence. Scale bars are $500 \mu \mathrm{m}$ in (a-f) and $200 \mu \mathrm{m}$ in (g-i). (a-c) is sample MSK5 and the remaining images are from sample MSK6. 

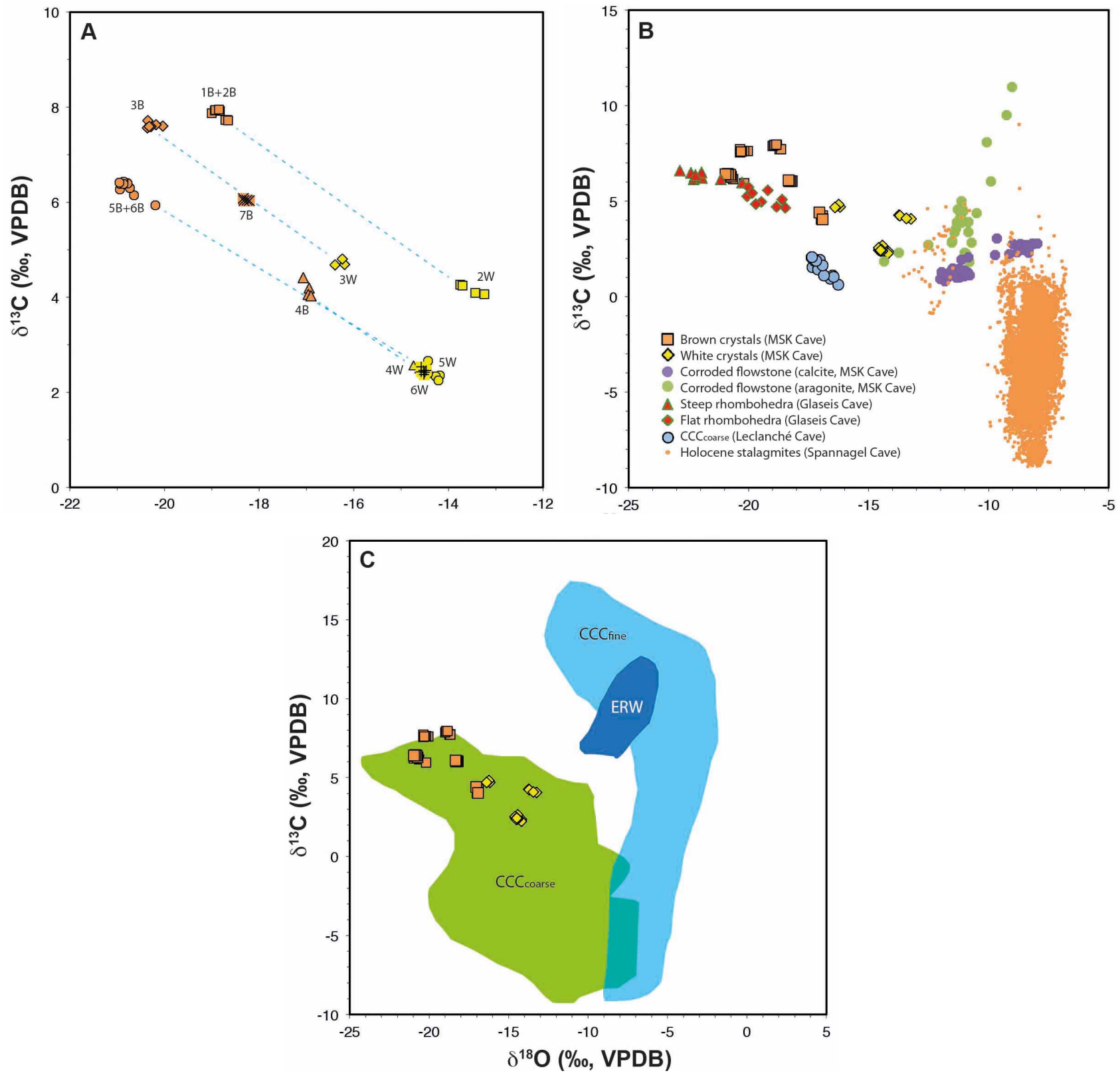

Figure 10. Stable isotopic composition of $\mathrm{CCC}_{\text {coarse }}$ samples from the two chambers in MSK Cave. Note different but equidistant scales on all three diagrams. (a) Brown (B) and white (W) crystal populations of individual CCC occurrences often show unique isotopic signatures. If both populations are present in one sample (as is the case for samples MSK2, 3, 4, 5 and 6), they define end members of linear relationships whose negative slopes are very similar. (b) Comparison of $\mathrm{CCC}_{\text {coarse }}$ samples from MSK Cave with $\mathrm{CCC}_{\text {coarse }}$ samples from Glaseis Cave (Richter et al., 2009), Leclanché Cave (Luetscher et al., 2013), inactive flowstone from the Eiskammer of MSK Cave and Holocene speleothems from nearby Spannagel Cave. The latter data set comprises data from 11 stalagmites, including the COMNISPA2

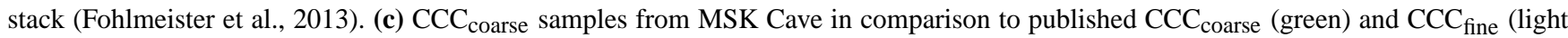
blue) data from non-Alpine caves in Romania, Slovakia, Poland, Czech Republic, Germany and Canada (data from Clark and Lauriol, 1992; Žák et al., 2004, 2009, 2012; Richter et al., 2013; Orvošová et al., 2014). The dark blue array labeled ERW shows data of in situ CCC from Eisriesenwelt in the Austrian Alps (Spötl, 2008).

We also observed moderately bright fluorescence in all crystal types under blue-light (and also under ultraviolet) excitation. Rather strong fluorescence was also observed - with the same microscope - in $\mathrm{CCC}_{\text {coarse }}$ from Leclanché Cave (Luetscher et al., 2013). Given the complete lack of soil above MSK Cave, we hypothesize that organic compounds produced in situ by microbial communities in the ice cave cause this fluorescence 
(rather than organics derived from the soil as is the case for stalagmites - e.g., McGarry and Baker, 2000). Very little is currently known about the microbiology of these cold, subterranean habitats, but existing data suggest the presence of a diverse and highly specialized ecosystem (e.g., Sattler et al., 2013; Hillebrand-Voiculescu et al., 2013).

(e) Characteristic stable isotopic composition. The C and $\mathrm{O}$ isotope values of MSK samples fall within the overall trend of $\mathrm{CCC}_{\text {coarse }}$ (Fig. 10) and hence support the model of very slow freezing and concomitant calcite precipitation (see Žák et al. (2012) for details about this process).

\subsection{Stable isotopes and the mode of $\mathrm{CCC}_{\text {coarse }}$ formation}

Separating crystal populations and analyzing their stable isotope composition yielded new insights into the mode of formation of $\mathrm{CCC}_{\text {coarse. }}$ Some earlier studies found differences in the isotopic composition of different types of crystals (e.g., Richter et al., 2009) and all studies reported a negative correlation between $\mathrm{C}$ and $\mathrm{O}$ isotope values (see summary chart in Žák et al., 2012). Our data from MSK Cave follow the same general trend but reveal that several of the heaps in the two chambers are characterized by a unique isotopic signature and that the two crystal populations always show large offsets at each site (Fig. 10). No intermediate samples were found suggesting that the brown and white crystal populations do indeed represent two distinct crystallization episodes. Given that the brown crystals show more evolved isotopic compositions, this implies that they probably formed after the white crystals. This is supported by the higher $\mathrm{U}$ concentration in the brown crystal fraction consistent with precipitation from water which became more enriched in ions due to progressive freezing. The ${ }^{230} \mathrm{Th}$ dates of the two crystal populations cluster tightly supporting the hypothesis that both crystal fractions formed within a short period of time (Fig. 11). Their age uncertainties would allow for up to a few hundred years of spread, but the observation that tie lines connecting the isotopic values of the brown and white end members of each heap are parallel to each other provides strong proof that several of these heaps originated from distinct small meltwater reservoirs which developed a unique isotopic composition upon refreezing. It is therefore appears highly unlikely that hundreds of years separated the two calcite generations, but rather a much shorter time span, probably a few years at most.

These isotopic observations add support to the model of $\mathrm{CCC}_{\text {coarse }}$ formation suggesting that these crystals originate in small pools of meltwater carved in cave ice (Žák et al., 2004; Richter and Riechelmann, 2008) and experiencing very slow refreezing under closed-system conditions (Kluge et al., 2014). Our data show that there were several such

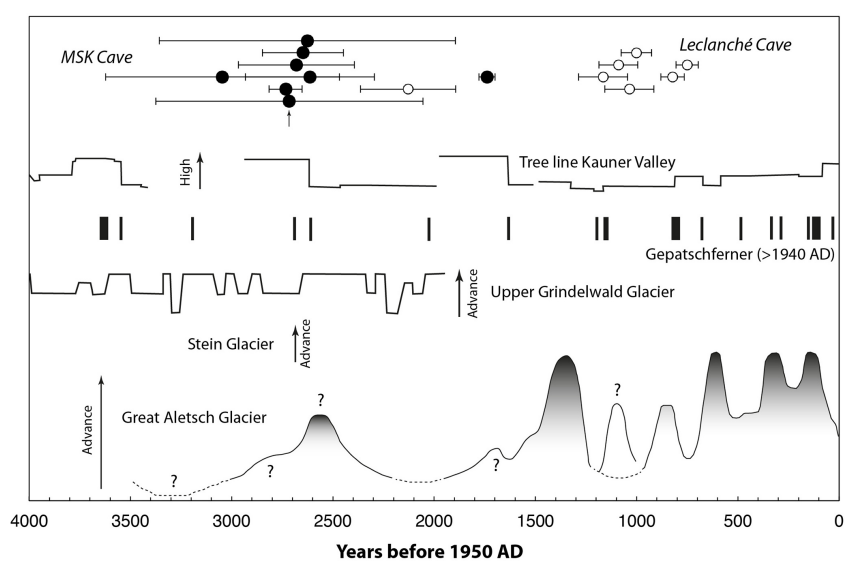

Figure 11. ${ }^{230} \mathrm{Th}$ dates of $\mathrm{CCC}_{\text {coarse }}$ from MSK Cave (filled circles) and the west-Alpine Leclanché Cave (open circles; Luetscher et al., 2013) compared to changes in the elevation of the tree line in the central-Alpine Kauner Valley (Nicolussi et al., 2005), advances of the east-Alpine Gepatsch Glacier beyond the extent of the 1940 AD glacier size (Nicolussi and Patzelt, 2001), a speleothembased record of the ice surface elevation of the Upper Grindelwald Glacier (Luetscher et al., 2011), ${ }^{10}$ Be-dated evidence of a marked advance of Stein Glacier, Switzerland (Schimmelpfennig et al., 2014), and a semicontinuous glacier-length record of the Great Aletsch Glacier in the Western Alps (Holzhauser et al., 2005) for the last four millennia. The only date of the white crystal fraction from MSK Cave is marked by a small vertical arrow.

water-filled depressions in the Eiskammer (manifested by the heaps of crystals, Fig. 3). Heaps no. 4, 5 and 6 occur within $3 \mathrm{~m}$ of this chamber and show a uniform isotopic composition of the white crystal fraction (Fig. 10), and evidence of a later pool separation leading to the formation of brown crystal fractions of different isotopic composition (Fig. 10). This suggests an initially larger pool in which the white crystals of these three heaps formed. In a second step, a smaller pool above heap no. 4 became isolated, whereas no. 5 and 6 seem to have remained one pool. Data from crystals heap no. 7, only about $1 \mathrm{~m}$ away from no. 6 (Fig. 3), fall on a different evolutionary line suggesting that they also formed in a separate pool. The same holds true for heap no. 3 a few meters down the chamber, as well as for $\mathrm{CCC}_{\text {coarse }}$ from the Kleine Eiskammer (Fig. 10). In the latter, much smaller chamber only one pool of meltwater seems to have existed as all isotope data plot on the same line (Fig. 10). Based on these findings and the cave survey we conclude that the diameters of these meltwater pools in which $\mathrm{CCC}_{\text {coarse }}$ formed typically ranged from about $0.5 \mathrm{~m}$ to as large as some $3 \mathrm{~m}$.

\subsection{Chronological issues}

${ }^{230}$ Th-dating allows us to place temporal constraints on when (a) ice was present in today's ice-free chambers of MSK Cave and (b) when the permafrost above the cave underwent degradation, releasing meltwater into the chamber which 
experienced progressive freezing. Excluding two highly impure samples (MSK4W and $5 \mathrm{~W}$ ), the remaining ${ }^{230}$ Th-dates cluster between 2600 and $3000 \mathrm{yr}$ BP; one sample suggests a younger precipitation phase at ca. $1700 \mathrm{yr}$ BP (Table 1). Unfortunately, only one sample of white crystals (MSK6W) yielded an acceptable result and this falls within the above mentioned range (Fig. 11). We therefore conclude that most of the brown and white CCC formed within a short time interval during the first half of the first millennium BC. This coincided with the transition from the Bronze to the Iron Age, which in the Alpine realm occurred at about $2800 \mathrm{yr}$ BP (Urban, 2000). As no record of past permafrost extent currently exists for the Alps, we compare our data to other paleoclimate archives. East- and west-Alpine glaciers show evidence of a major advance during the first half of the Bronze Age (culminating at ca. $3500 \mathrm{yr} \mathrm{BP}$, known as Löbben oscillation; Patzelt and Bortenschlager, 1973; Nicolussi and Patzelt, 2001; Holzhauser et al., 2005; Ivy-Ochs et al., 2009; Luetscher et al., 2011) followed by a retreat during the second half of the Bronze Age and centered at about $3300 \mathrm{yr}$ BP (Holzhauser et al., 2005; Joerin et al., 2006; Luetscher et al., 2011). Glaciers re-advanced during the early Iron Age, reaching a maximum at ca. $2600 \mathrm{yrBP}$ (Fig. 11). The extent of this glacier maximum is not precisely known but was likely smaller than during the Little Ice Age (Holzhauser et al., 2005; Holzhauser, 2008; K. Nicolussi, personal communication, 2013). Recent high-sensitivity ${ }^{10} \mathrm{Be}$ dating of moraine boulders at Stein Glacier, Central Alps of Switzerland, constrained this advance to $2690 \pm 130 \mathrm{yr}$ BP (reported as $2750 \pm 130$ before the year $2010 \mathrm{AD}$; Schimmelpfennig et al., 2014) and its extent was similar to that of the Little Ice Age. This "glacier-friendly" period is also reflected by a marked drop in the tree line in the western Austrian Alps during the Iron Age, following high tree lines during the early part of the first millennium BC (Fig. 11; Nicolussi et al., 2005). At the same time the Upper Grindelwald Glacier advanced as shown by speleothem data in the adjacent Milchbach Cave (Luetscher et al., 2011). High lake levels recorded in the Jura Mountains (Magny, 2004) and at Lago di Ledro in the Southern Alps (Magny et al., 2012) suggest a cool and wet climate during the middle of the first millennium BC. One sample of MSK Cave yielded a significantly younger date which suggests calcite precipitation ca. $1700 \mathrm{yr}$ BP when Gepatsch and Great Aletsch Glacier also experienced a minor advance.

\subsection{Do $\mathrm{CCC}_{\text {coarse }}$ record a regional permafrost signal?}

Many ice caves represent local thermal anomalies, whereby processes such as seasonal air flow or trapping of cold winter air set the stage for perennial ice accumulations at elevations much lower than the present-day lower limit of discontinuous permafrost (e.g., Perşoiu and Onac, 2012; Luetscher, 2013). Although the geometry of MSK Cave bears similarities with cold trap-type ice caves, several lines of observations suggest that this cave did not behave like an undercooled ice cave, but was - until very recently - part of a larger permafrost region.

(a) The entrance is located at $2558 \mathrm{~m}$, which is at the threshold of modern discontinuous permafrost in the western Central Alps of Austria (2500-2600 m; e.g., Krainer and Ribis, 2012), in particular when taking into account the NW-facing orientation of the cirque in which the cave opens.

(b) Rock glaciers occupy this cirque as well as several others along the Tuxer Hauptkamm and reach down to as low as $2250 \mathrm{~m}$. These rock glaciers are active, as shown by their steep fronts showing frequently falling blocks, complete lack of vegetation and fresh surfaces of the rock fragments (e.g., Zasadni, 2007).

(c) The presence of $\mathrm{CCC}_{\text {coarse }}$ itself argues strongly against MSK Cave being an undercooled cave unrelated to regional permafrost because the seasonally controlled air exchange in such "normal" ice caves creates temperature gradients too steep to allow $\mathrm{CCC}_{\text {coarse }}$ to form; only $\mathrm{CCC}_{\text {fine }}$ is known to form in some Alpine ice caves today (e.g., Spötl, 2008).

We therefore regard MSK Cave as part of the discontinuous mountain permafrost in the Tuxer Hauptkamm which has undergone thawing, likely due to the rise in air temperature since the end of the Little Ice Age. The magnitude of this warming trend has been twice as high in the Alps as compared to the mean of the Northern Hemisphere (e.g., Auer et al., 2007). As a consequence, the equilibrium line altitude of the glaciers in the Zemmgrund region, $13 \mathrm{~km}$ southeast of MSK Cave, has increased by as much as $120-130 \mathrm{~m}$ between 1850 AD and today (Schwendinger and Pindur, 2007), which provides some constraints on the concomitant rise of the permafrost boundary in the study area.

We hypothesize that the entrance to the cave was initially sealed permanently by ice-cemented debris which resulted in stable thermal conditions required for $\mathrm{CCC}_{\text {coarse }}$ to form. This might also explain why the cave was only discovered in 2004, although the area had been searched for caves before (R. Erler, personal communication, 2004). The cave temperature data strongly suggest that even today the entrance commonly gets closed by snow drift preventing the very cold midwinter air to descend into the cave (Fig. 5).

\section{5 $\quad \mathrm{CCC}_{\text {coarse }}$ formation at MSK Cave}

The radiometric dates provide unequivocal evidence that ca. $2600 \mathrm{yr}$ BP ice was present in MSK Cave (whose entrance was most likely sealed) and stable conditions close to the freezing point gave rise to $\mathrm{CCC}_{\text {coarse }}$ formation. The presence of drip water feeding the pools on the ice (and delivering ions, including uranium) indicates that the karstified marble above the cave was not completely frozen. It is interesting to note that the timing of this cryogenic carbonate 
precipitation event did not coincide with one of the "climate optima" during the Holocene, but with a time interval when several Alpine glaciers experienced a moderate advance following a warm interval. This suggests that the mechanism of permafrost degradation as a trigger for the formation of $\mathrm{CCC}_{\text {coarse }}$ may be more complex than previously thought.

Richter et al. (2010) proposed a model linking $\mathrm{CCC}_{\text {coarse }}$ formation in the Herbstlabyrinth-Advent Cave System (western Germany) to the stadial-interstadial climate rhythm of the last glacial period. Their model uses three critical assumptions:

(a) The lower limit of the permafrost zone stayed below the cave chamber during the entire stadial-interstadial cycle. Given that the sampled cave chamber is overlain by $40 \mathrm{~m}$ of rock, this provides a minimum depth for the lower permafrost boundary at this German site.

(b) During interstadial warming the upper boundary of the permafrost expanded downward into the frozen rock and eventually intersected the cavity.

(c) The $0{ }^{\circ} \mathrm{C}$ isotherm remained sufficiently long in this narrow zone to allow $\mathrm{CCC}_{\text {coarse }}$ to form in meltwater pools on the ice. Had the base of the active layer lowered by only a few more meters, the entire cave chamber would have become deglaciated; conversely, a slight rise of this boundary would cause the chamber to freeze completely. If this model is correct, a delicate balance has to be maintained in order to allow $\mathrm{CCC}_{\text {coarse }}$ to form in a given cave chamber. The time constant involved in the formation of $\mathrm{CCC}_{\text {coarse }}$ is currently unknown and likely varied given the range in crystal (aggregate) size and habit.

A corollary of the Richter et al. (2010) model is that there should be a unique combination between the magnitude of atmospheric warming and the possible formation of $\mathrm{CCC}_{\text {coarse }}$ in certain parts of a cave. In other words, for different atmospheric temperature increases, corresponding depth "windows" open up in the subsurface. If these "windows" intersect a subsurface cavity in the permafrozen ground, $\mathrm{CCC}_{\text {coarse }}$ can possibly form therein. In karstified carbonate rocks heat transfer occurs not only by conduction (as implicitly assumed by the Richter et al. (2010) model), but dominantly by advection due to infiltrating water, which introduces significant heterogeneity into the distribution of permafrost in the subsurface and complicates the relationship between climate forcing and $\mathrm{CCC}_{\text {coarse }}$ formation.

At MSK Cave stable thermal conditions close to $0{ }^{\circ} \mathrm{C}$ were only established during the cooling period centered around $2600 \mathrm{yr}$ BP, allowing $\mathrm{CCC}_{\text {coarse }}$ to form. This occurred several hundred years after the onset of warming (and presumable permafrost thawing). The observation that $\mathrm{CCC}_{\text {coarse }}$ formation apparently lagged atmospheric warming is consistent with the model of Richter et al. (2010) for the last glacial period. The authors suggested that $\mathrm{CCC}_{\text {coarse }}$ did not form during the peak interstadial, but in response to the subsequent cooling when the $0^{\circ} \mathrm{C}$ isotherm started to rise again. There is some indication that the conditions for $\mathrm{CCC}_{\text {coarse }}$ formation were met again in MSK Cave at about $1700 \mathrm{yr}$ BP and we note that this occurred again during a time interval when tree line and glacier data suggest a cooling (Fig. 11).

\section{Conclusions and implications}

$\mathrm{CCC}_{\text {coarse }}$ provides critically needed temporal constraints on the former presence of ice in the subsurface. Data from caves of different settings, however, may yield partly inconsistent results because the relationship between atmospheric warming, degradation of mountain permafrost tens of meters below the surface and the eventual precipitation of cryogenic calcite is sensibly dependent on parameters such as the elevation (and hence temperature) of the cave, the thickness of the rock overburden, the nature of the water infiltration regime and the magnitude and rate of climate change. The only other study of dated $\mathrm{CCC}_{\text {coarse }}$ from an Alpine ice cave linked these to warm temperatures during the Medieval Warm Period and the Roman Warm Period (Luetscher et al., 2013). Two of the data points, however, suggest calcite growth ca. 700$750 \mathrm{yr}$ BP, i.e., at the onset of the Little Ice Age, when temperatures dropped and glaciers started to gain mass.

$\mathrm{CCC}_{\text {coarse }}$ data record apparently quite delicate thermal conditions in the subsurface which have to be considered in their site-specific context, and the data from MSK Cave illustrate this point nicely: apart from a single data point at ca. $1700 \mathrm{yr} \mathrm{BP}$, there is no evidence of $\mathrm{CCC}_{\text {coarse }}$ precipitation during any of the other warming-cooling periods of the Holocene nor during the preceding Lateglacial period. The studies from MSK and Leclanché Cave demonstrate that $\mathrm{CCC}_{\text {coarse }}$ formation occurred until recently in high-Alpine sites, but the precise conditions that lead to their growth are still incompletely understood. Future work on $\mathrm{CCC}_{\text {coarse }}$ should therefore move along three routes: (a) enlarging the database of chronologically well-constrained Holocene occurrences in permafrost regions (high mountain ranges, polar regions) and comparing these to regional paleoclimate records; (b) searching for sites where $\mathrm{CCC}_{\text {coarse }}$ is forming today; this represents a daunting task (and may require technically challenging ice-drilling), but would finally allow us to validate the pool model and might offer the opportunity to study the little-known microbial communities dwelling in cave ice and water pockets therein; (c) precipitating $\mathrm{CCC}_{\text {coarse }}$ in the laboratory under controlled conditions to better understand the origin of the great variety of cryogenic calcite particles; similar experiments have already been performed in order to assess the possible occurrence of cryogenic carbonates on Mars (Socki et al., 2010, 2014). 
Acknowledgements. C. Spötl is grateful to Roman Erler for introducing him to MSK Cave, Gina Moseley for logistic support in the cave, Robbie Shone for providing pictures from the cave, Kristian Pfaller for FE-SEM images, Boris Ilyashuk for reflected-light images, Richard Tessadri and Daniela Schmidmair for XRD analyses and Marc Luetscher for reading an earlier version and providing helpful comments, as well as to K. Žák and an anonymous journal referee for constructive criticism. Partial support by the Austrian Science Fund (FWF, project P206180) is acknowledged.

Edited by: D. Fleitmann

\section{References}

Auer, I., et al.: HISTALP - Historical instrumental climatological surface time series of the greater Alpine region 1760-2003, Int. J. Climatol., 27, 17-46, 2007.

Boeckli, L., Brenning, A., Gruber, S., and Noetzli, J.: Permafrost distribution in the European Alps: calculation and evaluation of an index map and summary statistics, The Cryosphere, 6, 807820, doi:10.5194/tc-6-807-2012, 2012.

Cheng, H., Edwards, R. L., Shen, C.-C., Polyak, V. J., Asmerom, Y., Woodhead, J., Hellstrom, J., Wang, Y., Kong, X., Spötl, C., Wang, X., and Alexander, E. C.: Improvements in ${ }^{230}$ Th dating, ${ }^{230} \mathrm{Th}$ and ${ }^{234} \mathrm{U}$ half-life values, and U-Th isotopic measurements by multi-collector inductively coupled plasma mass spectrometry, Earth Planet. Sc. Lett., 371-372, 82-91, 2013.

Clark, I. D. and Lauriol, B.: Kinetic enrichment of stable isotopes in cryogenic calcites, Chem. Geol., 102, 217-228, 1992.

Erlemeyer, M., Hasenmayer, B., and Schudelski, A.: Das Höhlensystem Kreiselhalle-Malachitdom - ein bemerkenswerter Aufschluß für Höhlenminerale, in: Der Malachitdom. Ein Beispiel interdisziplinärer Höhlenforschung im Sauerland, 6989, Krefeld (Geol. Landesamt Nordrhein-Westfalen), 1992.

Fohlmeister, J., Vollweiler, N., Spötl, C., and Mangini, A., COMNISPA II: update of a mid-European isotope climate record, 11 ka to present, The Holocene, 23, 749-754, 2013.

Gruber, S., Hoelzle, M., and Haeberli, W.: Permafrost thaw and destabilization of alpine rock walls in the hot summer of 2003, Geophys. Res. Lett., 31, L13504, doi:1029/2004GL020051, 2004.

Hillebrand-Voiculescu, A., Iţcus, C., Rusu, A., Popa, E., Pascu, E., Ardelean, I., Perşoiu, A., Brad., T., Onac, B. P., and Purcarea, C.: Unravelling underground ice microcosms. $16^{\text {th }}$ Intern. Congress Speleology, Brno, Czech Republic, July 21-28, 2013, Proceedings, edited by: Filippi, M. and Bosák, P., Praha (Czech Speleological Society), 1, p. 401, 2013.

Holzhauser, H.: Dendrochronologische Auswertung fossiler Hölzer zur Rekonstruktion der nacheiszeitlichen Gletschergeschichte, Bull. Angew. Geol., 13, 23-41, 2008.

Holzhauser, H., Magny, M., and Zumbühl, H. J.: Glacier and lakelevel variations in west-central Europe over the last 3500 years, The Holocene, 15, 789-801, 2005

Huggel, C., Salzmann, N., Allen, S., Caplan-Auerbach, J., Fischer, L., Haeberli, W., Larsen, C., Schneider, D., and Wessels, R.: Recent and future warm extreme events and high-mountain slope stability, Philos. T. R. Soc. A, 368, 2435-2459, 2010.

Ivy-Ochs, S., Kerschner, H., Maisch, M., Christl, M., Kubik, P. W., and Schlüchter, C.: Latest Pleistocene and Holocene glacier vari- ations in the European Alps, Quat. Sci. Rev., 28, 2137-2149, 2009.

Joerin, U. E., Stocker, T. F., and Schlüchter, C.: Multicentury glacier fluctuations in the Swiss Alps during the Holocene, The Holocene, 16, 697-704, 2006.

Kluge, T., Marx, T., Aeschbach-Hertig, W., Spötl, C., and Richter, D. K.: Noble gas concentrations in fluid inclusions as tracer for the origin of coarse-crystalline cryogenic cave carbonates, Chem. Geol., 368, 54-62, 2014.

Krainer, K. and Ribis, M.: A rock glacier inventory of the Tyrolean Alps (Austria), Austrian J. Earth Sci., 105, 35-47, 2012.

Luetscher, M.: Glacial processes in caves, in: Treatise on Geomorphology, edited by: Shroder, J. and Frumkin, A., Academic Press, San Diego, CA, Karst Geomorphology, 6, 258-266, 2013.

Luetscher, M., Bolius, D., Schwikowski, M., Schotterer, U., and Smart, P. L., Comparison of techniques for dating of subsurface ice from Monlesi ice cave, Switzerland, J. Glaciol., 53, 374-384, 2007.

Luetscher, M., Hoffmann, D., Frisia, S., and Spötl, C.: Holocene glacier history from alpine speleothems, Milchbach cave, Switzerland, Earth Planet. Sc. Lett., 302, 95-106, 2011.

Luetscher, M., Borreguero, M., Moseley, G. E., Spötl, C., and Edwards, R. L.: Alpine permafrost thawing during the Medieval Warm Period identified from cryogenic cave carbonates, The Cryosphere, 7, 1073-1081, doi:10.5194/tc-7-1073-2013, 2013.

Magny, M.: Holocene climate variability as reflected by midEuropean lake-level fluctuations andits probable impact on prehistoric human settlement, Quaternary Int., 113, 65-79, 2004.

Magny, M., Joannin, S., Galop, D., Vannière, B., Haas, J. N., Bassetti, M., Bellintani, P., Scandolari, R., and Desmet, M. N.: Holocene palaeohydrological changes in the northern Mediterranean borderlands as reflected by the lake-level record of Lake Ledro, northeastern Italy, Quat. Res., 77, 382-396, 2012.

May, B., Spötl, C., Wagenbach, D., Dublyansky, Y., and Liebl, J.: First investigations of an ice core from Eisriesenwelt cave (Austria), The Cryosphere, 5, 81-93, doi:10.5194/tc-5-81-2011, 2011.

McGarry, S. F. and Baker, A.: Organic acid fluorescence: application to speleothem palaeoenvironmental reconstruction, Quat. Sci. Rev., 19, 1087-1101, 2000.

Nicolussi, K. and Patzelt, G.: Untersuchungen zur holozänen Gletscherentwicklung von Pasterze und Gepatschferner (Ostalpen), Z. Gletscherk. Glazialgeol., 36, 1-87, 2001.

Nicolussi, K., Kaufmann, M., Patzelt, G., van der Plicht, J., and Thurner, A.: Holocene tree-line variability in the Kauner Valley, central Eastern Alps, indicated by dendrochronological analysis of living trees and subfossil logs, Veget. Hist. Archaeobot., 14, 221-234, 2005.

Orvošová, M., Deiniger, M., and Milovsky, R.: Permafrost occurrence during the Last Permafrost Maximum in the Western Carpathian Mountains of Slovakia as inferred from cryogenic cave carbonate, Boreas, 43, 750-758, 2014.

Patzelt, G. and Bortenschlager, S.: Die postglazialen Gletscher- und Klimaschwankungen in der Venedigergruppe (Hohe Tauern, Ostalpen), Z. Geomorph. Suppl., 16, 25-72, 1973.

Perşoiu, A. and Onac, B.: Ice in caves, in: Encyclopedia of caves, 2nd Ed., edited by: Culver, D. C. and White, W. B., Amsterdam (Elsevier), 399-404, 2012. 
Richter, D. K. and Riechelmann, D. F. C.: Late Pleistocene cryogenic calcite spherolites from the Malachitdom Cave (NE Rhenish Slate Mountains, Germany): origin, unusual internal structure and stable C-O isotope composition, Intern. J. Speleol., 37, 119129, 2008.

Richter, D. K., Voigt, S., and Neuser, R. D.: Kryogene Calcite unterschiedlicher Kristallform und Kathodolumineszenz aus der Glaseishöhle am Schneiber (Steinernes Meer/Nationalpark Berchtesgaden, Deutschland), Die Höhle, 60, 3-9, 2009.

Richter, D. K., Meissner, P., Immenhauser, A., Schulte, U., and Dorsten, I.: Cryogenic and non-cryogenic pool calcites indicating permafrost and non-permafrost periods: a case study from the Herbstlabyrinth-Advent Cave system (Germany), The Cryosphere, 4, 501-509, doi:10.5194/tc-4-501-2010, 2010.

Richter, D. K., Meyer, S., Scholz, D., and Immenhauser, A.: Multiphase formation of Weichselian cryogenic calcites, Riesenberg Cave (Süntel/NW Germany), Z. Dt. Ges. Geowiss., 164, 353367, 2013.

Sattler, B., Larch, P., Rambacher, J., and Spötl, C.: Das Eis der Hundsalm Eis- und Tropfsteinhöhle als Lebensraum für mikrobielle Gemeinschaften, Die Höhle, 64, 15-24, 2013.

Schimmelpfennig, I., Schaefer, J. M., Akcar, N, Koffman, T., OvyOchs, S., Schwartz, R., Finkel, R. C., Zimmerman, S., and Schlüchter, C.: A chronology of Holocene and Little Ice Age glacier culminations of the Steingletscher, CentralAlps, Switzerland, based on high-sensitivity beryllium-10 moraine dating, Earth Planet. Sc. Lett., 393, 220-230, 2014.

Schöner, W., Boeckli, L., Hausmann, H., Otto, J.-C., Reisenhofer, S., Riedl, C., and Seren, S.: Spatial patterns of permafrost at Hoher Sonnblick (Austrian Alps) - Extensive field-measurements and modelling approaches, Aust. J. Earth Sci., 105, 154-168, 2012.

Schwendinger, G. and Pindur, P.: Die Entwicklung der Gletscher im Zemmgrund seit 1850 - Längenänderung, Flächen- und Volumenverlust, Schneegrenzanstieg, in: Prähistorische Lawinen. Nachweis und Analyse holozäner Lawinenereignisse in den Zillertaler Alpen, edited by: Luzian, R. and Pindur, P., Österreich. Mitt. Komm. Quartärforschung Österr. Akad. Wiss. (Vienna), 16, 53-68, 2007.

Socki, R. A., Niles, P. B., Fu, Q., and Gibson, E. K.: Cryogenic carbonate formation on Mars: clues from stable isotope variations seen in experimental studies, $41^{\text {st }}$ Lunar and Planetary Science Conference, available at: http://www.lpi.usra.edu/meetings/ lpsc2010/pdf/2526.pdf, 2010.
Socki, R. A., Niles, P. B., Sun, T., Fu, Q., Romanek, C. S., and Gibson, E. K.: Martian cryogenic carbonate formation: stable isotope variations observed in laboratory studies, $45^{\text {th }}$ Lunar and Planetary Science Conference, available at: http://www.hou.usra.edu/ meetings/lpsc2014/pdf/2757.pdf, 2014.

Spötl, C.: Kryogene Karbonate im Höhleneis der Eisriesenwelt, Die Höhle, 59, 26-36, 2008.

Spötl, C. and Vennemann, T. W.: Continuous-flow IRMS analysis of carbonate minerals, Rap. Commun. Mass Sp., 17, 1004-1006, 2003.

Springman, S. M., Yamamoto, Y., Buchli, T., Hertrich, M., Maurer, H., Merz, K., Gärtner-Roer, I., and Seward, L.: Rock glacier degradation and instabilities in the European Alps: A characterization and monitoring experiment in the Turtmanntal, $\mathrm{CH}$, in: Landslide Science and Practice, edited by: Margottini, C., Canuti, P. and Sassa, K., 4, 5-13, doi:10.1007/978-3-642-313370_1, 2013.

Urban, O. H.: Der lange Weg zur Geschichte, Die Urgeschichte Österreichs bis 15 v. Chr, in: Österreichische Geschichte, edited by: Wolfram, H., 511 pp., Vienna (Ueberreuter), 2000.

Žák, K., Urban, J., Cilek, V., and Hercman, H.: Cryogenic cave calcite from several Central European caves: ages, carbon and oxygen isotopes and a genetic model, Chem. Geol., 206, 119-136, 2004.

Žák, K., Onac, B. P., and Perşoiu, A.: Cryogenic carbonates in cave invironments: A review, Quaternary Int., 187, 84-96, 2008.

Žák, K., Hercman, H., Orvošová, M. and Jačková, I.: Cryogenic cave carbonates from the Cold Wind Cave, Nízke Tatry Mountains, Slovakia: Extending the age range of cryogenic cave carbonate formation to the Saalian, Intern. J. Speleol., 38, 139-152, 2009.

Žák, K., Richter, D. K., Filippi, M., Živor, R., Deininger, M., Mangini, A., and Scholz, D.: Coarsely crystalline cryogenic cave carbonate - a new archive to estimate the Last Glacial minimum permafrost depth in Central Europe, Clim. Past, 8, 1821-1837, doi:10.5194/cp-8-1821-2012, 2012.

Žák, K., Orvošová, M., Filippi, M., Vlček, L., Onac, B. P., Perşoiu, A., Rohovec, J. and Světlík, I.: Cryogenic cave pearls in the periglacial zones of ice caves, J. Sed. Res., 83, 207-220, 2013.

Zasadni, J.: The Little Ice Age in the Alps: its record in glacial deposits and rock glacier formation, Studia Geomorphologica Carpatho-Balcanica, 41, 117-137, 2007. 